\title{
A Comparative Study of High Level laser and Low Level laser and Temperature on the Erythrocytes Sedimentation Rate Values in Healthy People : In Vitro Study
}

\author{
Assistant Lecturer Ferial.Y.Nazal ferial-y@utq.edu.iq
}

University of Thi-Qar / College of Medicine / Dept. of Physiology \& Medical Physics

\begin{abstract}
$\underline{\text { Abstract }}$
Background :The effects of laser irradiation with 632.8 and $2100 \mathrm{~nm}$ on Erythrocyte Sedimentation Rate (ESR) in blood samples from healthy peopleblood were comparatively studied in vitro and study the effect of environmental temperature.

Objective : This study was designed to show the effect of He-Ne laser, HO-YAG laser and effect of environmental temperature on Erythrocyte Sedimentation Rate (ESR) .

Subject \& Methods : The study of case - control cross sectional design included 40healthy persons (male and female) with age group (20-45 year), Workplace in the laboratory of physiology and medical physicsthe time between April 2016 to July 2016.

He-Ne laser (LJL 40-HA, Shanghai Research Institute of Laser Technology) wave length of $632.8 \mathrm{~mm}$ was used for irradiation with $5 \mathrm{~mm}$ diameter beam spot on blood samples, with power density $30 \mathrm{mw} / \mathrm{cm}^{2}$ and $\mathrm{HO}-Y A G$ laser irradiation wave length $2100 \mathrm{~nm}$ ( Karl Storz - Endoskope, Germany ),output power is ( 0.5J).The irradiation times were (5min ), The samples of blood were obtained from 40 contributors and each sample was separated into three samples for irradiation and control .All statistical analysis was performed withstatistical package graph Pad software For those with significant difference.
\end{abstract}

\section{Results :}

The results showed that there were significant differences in the values of sedimentation rates for both class (15-45) ${ }^{0} \mathrm{c}$ degree heat compared with the values of sedimentation 15 ${ }^{0} \mathrm{c}$ degree heat temperature for irradiation and control

It shows the effect of temperature factor on the red blood cells sedimentation rate in blood samples from healthy people and see the effect of the degree of laboratory heat due to lack of efficient heating and cooling devices in the summer and winter on the sedimentation rates of values to be taken into consideration with the results. We observe irradiation $632.8 \mathrm{~nm}$ laser decreases ESR while irradiation at $2100 \mathrm{~nm}$ increases ESR with $\mathrm{p}<0.01$.

Conclusion:The change of temperature (high and low) has a great effect on precipitation of red blood cells in health people and thus must be taken into consideration and this effect also observed with the use of632.8 and $2100 \mathrm{~nm}$ on Erythrocyte Sedimentation Rate (ESR) in blood samples from healthy individuate blood were comparatively studied in vitro at a temperature of $15{ }^{\circ} \mathrm{C}$.We observe irradiation $632.8 \mathrm{~nm}$ laser decreases ESR while increasing irradiation at $2100 \mathrm{~nm}$ with $\mathrm{p}<0.01$.

Keywords:Helium Neon laser, Holmium-YAG laser,Erythrocytes Sedimentation Rate (ESR), Temperature. 


\section{Introduction}

The erythrocyte sedimentation rate is one of the most important principles underlying the Greek medicine, where it was discovered by the scientists of physics Sweden since 1915 and adopted by the Greeks in ancient medicine. the principles of this test established since the fifth century BC and subsequently developed by the worlds Aristotle ${ }^{[1][2]}$. As the deposition rate for the diagnosis of inflammation associated with acute cases and cancers ${ }^{[3]}$.depends on lasers effect on objects wavelength, light intensity , etc ${ }^{[4]}$, laser irradiation causes the optical interaction with cells instead of thermal effect.

Laser irradiation in this red spectral area increases the proliferative activity of cells and promotes tissue repair ${ }^{[5]}$.the use of high-energy, especially in the surgical lasers leads to the destruction of tissue ${ }^{[6]}$. There are Several methods for determination of the ESR, westergren method, wintrobes method, landu method ${ }^{[7]}$.The holmium laser, Ho: YAG, has an infrared wavelength of $2100 \mathrm{~nm}$. It is a perfect lithotripter, suitable for all types of fragmentation of urinary stones due to the impact of the strong photo acoustic effect and high peak power. The optical penetration is up to 0.4 $\mathrm{mm}$, but because of higher absorption through the water ${ }^{[8]}$.Most of the authors have recommended the use of $0.2-0.8$ joules at $10-20$ pulses per second. Holmium laser at the wave length of $2100 \mathrm{~nm}$ has clinically very important physical properties owing to a balance between the coefficients of absorption and scatter. The property of a laser to be absorbed by the incident target (in the present context human tissue) gives it the ability to cut sharply, and is described as the coefficientof absorption. Carbon dioxide laserhappens to be on one end of the spectrum with one of the sharpest cutting lasers ${ }^{[9]}$.

ESR based on the principle of deposition rate of RBCin the bottom of the test tube and separated from the yellow liquid (plasma)which will be in the top ${ }^{[10]}$.

Physiological factors that have an impact on sedimentation friction force on the red cell and change the surface of cells ${ }^{[3]}$.the effect of the low level laser irradiation on blood is very serious $^{[11]}$, laser generally used now a day is the low-level laser are He-Ne laser emitting light at a wavelength of $632.8 \mathrm{~nm}^{[12][13]}$. In laser- tissue interaction, the incidence of laser light on the certain tissue may be undergoing reflection, scattering, transmission or absorption. The effects of lasers on biological tissue are complex processes resulting from two interaction mechanisms: wavelength dependent interaction mechanism that includes: photothermal and photochemical interactions ${ }^{[14]}$. Interest in biostimulation effect of low intensity $\mathrm{He}-\mathrm{Ne}$ laser, has increased in the last few years and the simulativeeffectiveness of electromagnetic radiation in the shape of low level laser light in biology and medicine ${ }^{[15]}$.

\section{Aim of the study}

To evaluate the effect of He-Ne laser, HO-YAG laser and effect of environmental temperature $(15,45)^{0} \mathrm{c}$ on Erythrocyte Sedimentation Rate (ESR). 


\section{Methods and Materials}

The study of case-control design included 40healthy persons (male and female ) with age group (20-45 year),Workplace in the laboratory of physiology and medical physicsthe time between April 2016 to July 2016.Blood samples collected in the anti-coagulant clean pipes with textured tri-sodium citrate anti-coagulant of 40 healthy donors between the ages of sample 20-45year of male and female method was used and known Westergren way by the world Organization for laboratory measurements National Committee of Clinical -Laboratory Standards ${ }^{[7]}$.pulling blood after mixing it quietly anticoagulant by Westergren absorbent and dry up to the mark $5 \mathrm{~mm}$ at the top of the tube with a note to avoid air bubbles in the blood column during the drag and fix pipes and put vertically on the stand. was used incubator seized every one of them to a certain temperature as selected temperatures are15 degree that should be tested sedimentation rate of any considered the degree of control that it compares the rest of the results in the other thermal grades represent room temperature ranging from (20-25) ${ }^{0} \mathrm{c}$, while proving the temperature of the incubator second at a temperature of $45^{\circ}$ cand so as a thermal class that link to it degree laboratory daytime temperatures in the summer as the room temperature range in summer $(40-50)^{0}$ cdegrees during the day inside the room . put the pipe carriers in each incubator and control the temperature of each incubator is $(15,45)^{0} \mathrm{c}$ and the samples were left in the incubator for one hour each degree heat was irradiated by He-Ne laser radiation ofthe fluence is $\left(4.5 \mathrm{~J} / \mathrm{cm}^{3}\right)$ and $\mathrm{Ho}-\mathrm{YAG}$ laser radiation of is $(75$ $\mathrm{J} / \mathrm{cm}^{3}$ ) were used. During experimentation, the laser beam was delivered to the tubes of blood $(2 \mathrm{ml})$ with an irradiation spot of the $5 \mathrm{~mm}$ diameterin the incubator $15^{\circ} \mathrm{c}$ degree and the second sample was kept without irradiation and served as control as a measure for comparison. That irradiation dose was reflected to be the laser energy per volume unit $\left(\mathrm{J} / \mathrm{cm}^{3}\right)$, irradiation time $(\mathrm{t})$ is $5 \mathrm{~min}$ and radiation doses were calculated using the equation:

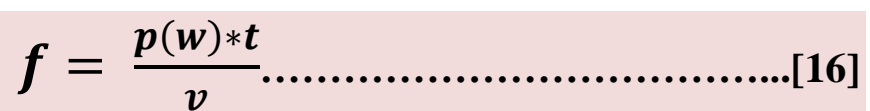

$$
\text { R.V. }=\frac{\Delta X}{X} \ldots . .[15]
$$

(where $\Delta \mathrm{X}$ is difference between before and after irradiation ).

The ESR ratio with laser radiation and red blood cells ESR(L) can be calculated by the following below equation :

$$
E S R(L)=\frac{E S R \text { with laser radiation }}{\text { ESR without laser radiation control }}
$$




\section{$\underline{\text { Results }}$}

The results showed that there were significant differences in the values of sedimentation rates for both class (15-45) ${ }^{0} \mathrm{c}$ degree heat compared with the values of sedimentation 15 ${ }^{0} \mathrm{c}$ degree heat temperature for irradiation and control .It shows the effect of temperature factor on the red blood cells sedimentation rate in blood samples from healthy people and see the effect of the degree of laboratory heat due to lack of efficient heating and cooling devices in the summer and winter on the sedimentation rates of values to be taken into consideration with the results and on this basis it was necessary to test the sedimentation rate at temperatures ranging from $(15-45)^{0} \mathrm{c}$ and the temperature rise most impact on sedimentation rates erythrocytes values it at a lower temperature .The ESR measurementsis shown in (Table 2) . (Table 3) show that for these blood samples which originally had abnormally high ESR values, We observe irradiation $632.8 \mathrm{~nm}$ laser decreases ESR while increasing irradiation at $2100 \mathrm{~nm}$ with $\mathrm{p}<0.01$. Table (1) shows the rates of sedimentation in the values of thermal grades $(15-45)^{0}$ crepresents (Means \pm Standard Deviation ) .

Table(1):Effect of Temperature on erythrocyte sedimentation rate (ESR )

$\mathrm{N}$ : Number of samples, $\mathrm{f}$ : female, $\mathrm{m}$ : male .

\begin{tabular}{|c|c|c|c|}
\hline \multicolumn{2}{|c|}{ Variable } & Mean \pm Std. & P-value \\
\hline $\mathbf{N}$ & Temperature/ ESR & & \\
\hline $\mathbf{f} / \mathbf{m}$ & $15 \mathrm{C}^{0}$ & $18.607 \pm 6.8230$ & $<0.01$ \\
\hline $\mathbf{2 3 / 1 7}$ & & & $<0.01$ \\
\hline $\mathbf{2 3 / 1 7}$ & $45 \mathrm{C}^{0}$ & $25.900 \pm 8.5151$ & \\
\hline
\end{tabular}


Table(2): The Effect of He-Ne laser irradiation on erythrocyte sedimentation rate (ESR) after $5 \mathrm{~min}$ irradiation ( irradiance $4.5 \mathrm{~J} / \mathrm{cm}^{3}$ ) $\mathrm{P}<0.01$.

R.V. : relative variance

\begin{tabular}{|c|c|c|}
\hline Temperature $\left(\mathbf{1 5} \mathbf{C}^{\mathbf{0}}\right)$ & Mean \pm Std. & P-value \\
\hline Control & $18.607 \pm 6.8230$ & $<0.01$ \\
\hline Irradiation & $19.0222 \pm 6.51332$ & $<0.01$ \\
\hline ESR $_{\mathbf{L}}$ & $1.0360 \pm 0.02383$ & $<0.01$ \\
\hline R.V. & $0.0432 \pm 0.02106$ & $<0.01$ \\
\hline
\end{tabular}

Table (3): The Effect of HO-YAG laser irradiation on erythrocyte sedimentation rate ESR after 5 min irradiation (irradiance $75 \mathrm{~J} / \mathrm{cm}^{3}$ ) $\mathrm{P}<0.01$.

\begin{tabular}{|c|c|c|}
\hline Temperature $\left(\mathbf{1 5} \mathbf{C}^{\mathbf{0}}\right)$ & Mean $\mathbf{\pm}$ Std. & P-value \\
\hline Control & $22.5000 \pm 8.48833$ & $<0.01$ \\
\hline Irradiation & $20.4667 \pm 8.41072$ & $<0.01$ \\
\hline ESR $_{\mathbf{L}}$ & $0.8877 \pm 0.05374$ & $<0.01$ \\
\hline R.V. & $0.1130 \pm 0.06293$ & $<0.01$ \\
\hline
\end{tabular}




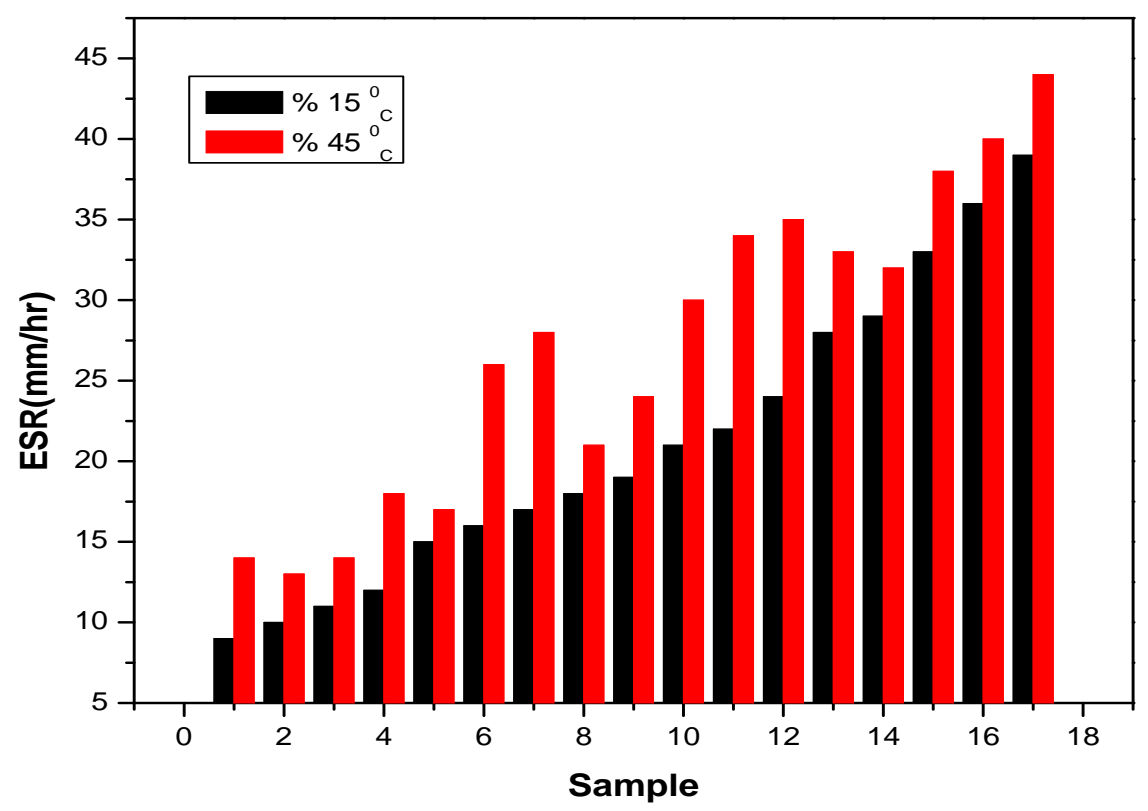

Figure (1) : Effect of Temperature $\left(15^{0} \mathrm{c}, 45^{\circ} \mathrm{c}\right)$ on erythrocyte sedimentation rate ESR for samples .

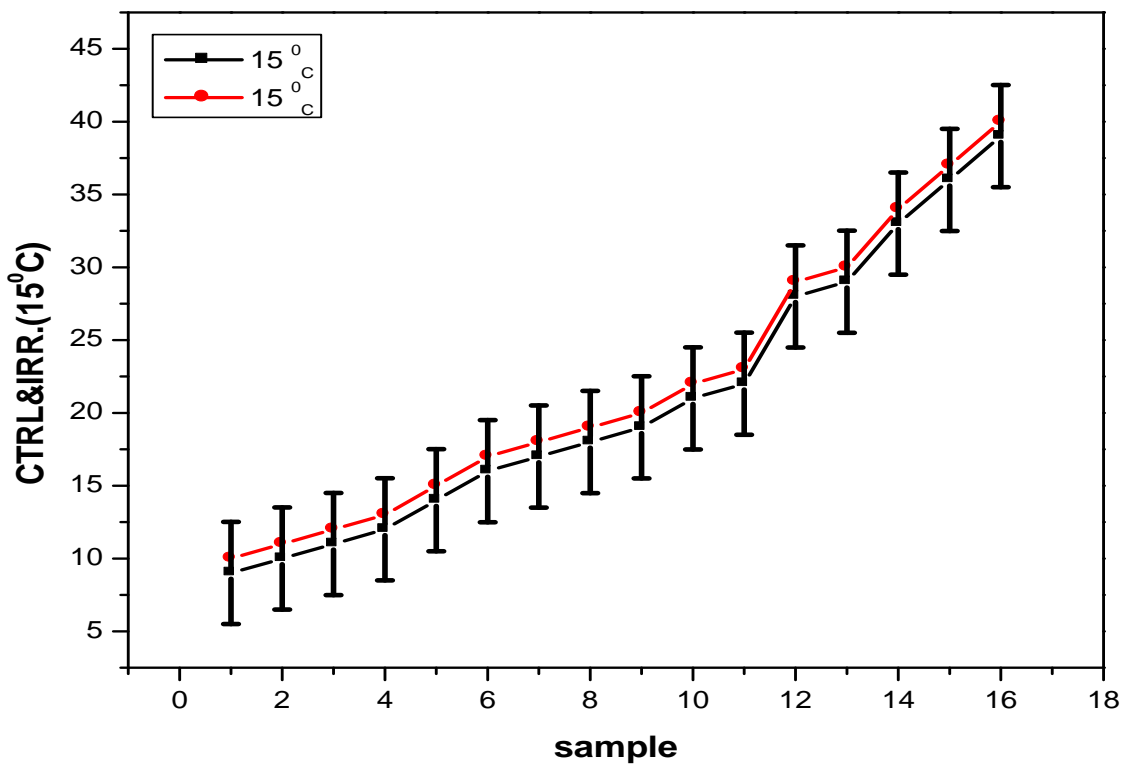

Figure (2) : The Effect of He-Ne laser irradiation on erythrocyte sedimentation rate ESR after 5 min irradiation . 


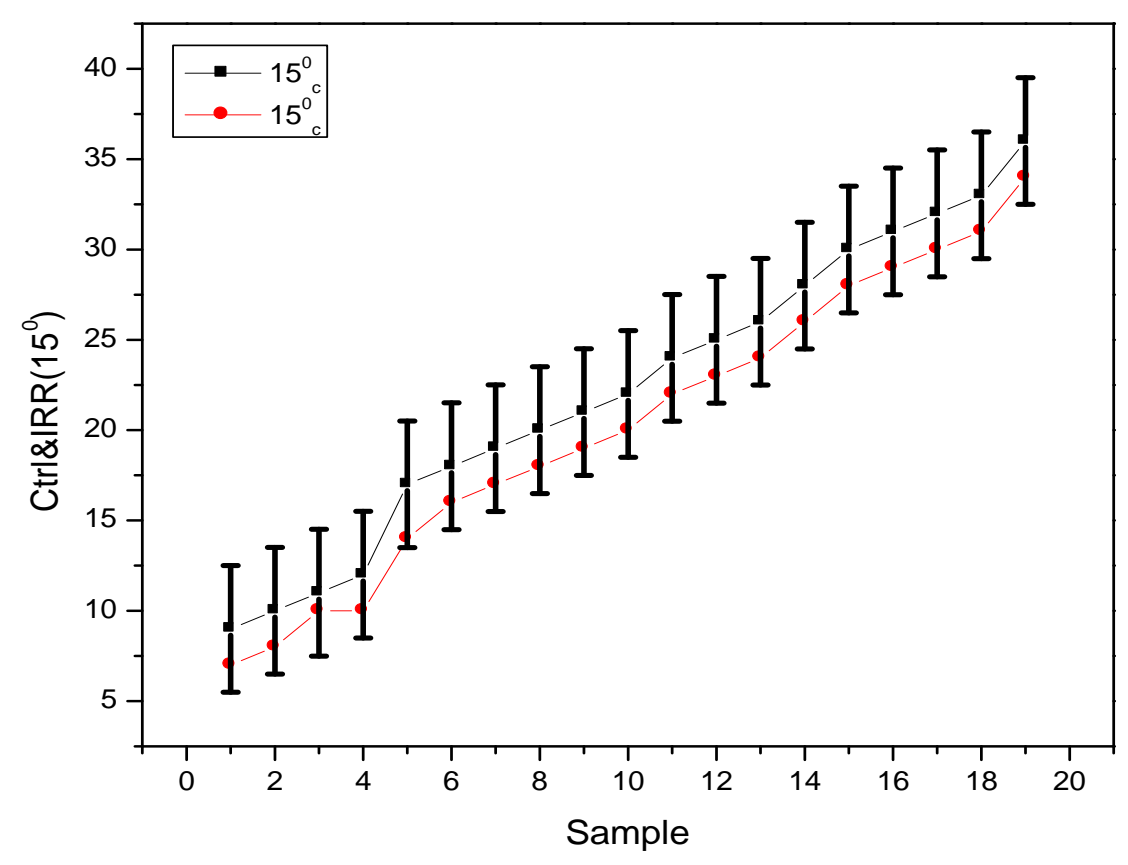

Figure (3) : The Effect of Ho-YAGlaser irradiation on erythrocyte sedimentation rate ESR after 5 min irradiation .

The results of the effects of laser irradiation before andafter irradiation are shown in the following table(2) and table (3) . A positive results in which the relative variation R.V. of a given between its value after irradiation and before irradiation .

\section{$\underline{\text { Statistics Analysis }}$}

In this work, Use statistical analysis to determine the effect of temperature on the values of the deposition erythrocytes rates using a statistical program and to compare the severity of the impact of the change in temperature on the deposition rate, compared with a temperature control $15{ }^{0} \mathrm{c}$ by taking data deviation values of sedimentation rates in degrees $15-45^{0} \mathrm{c}$ a average data sedimentation rates in the values of temperature control $15^{0} \mathrm{c}$

the most crucial concern is the difference between the control and laser irradiation thus ttestwas used to evaluate the difference between the irradiated samplesand non-irradiated control. All statistical analysis was performed withstatistical package graph Pad software For those with significant difference, thepercentage of relative variance (R.V.) was calculated to evaluate theextent of the relative change between irradiated and nonirradiatedsamples. 


\section{$\underline{\text { Discussion }}$}

Sedimentation values affected by a number of factors, Some of them biological especially red blood cellswhile others are physically, the circumstances surrounding in the labor . materials and equipment used in this research were all factors affecting the values of sedimentation rates. Results showed values of the rates of sedimentation occurred within the normal rates when comparing with the natural values included in global measures mentioned by which range between $(6-19) \mathrm{mm} / \mathrm{h}$ at $15^{\circ} \mathrm{C}$. The decline in temperature and height from 15 to 45 to the direct impact on the values of sedimentation rates clearly, as the high temperature offset by a rise in the values of sedimentation rates, as it is the temperature factor one of the factors affecting the values of ESR and through the direct impact on the attractive forces of cell blood red, as increasingly attractive forces of erythrocytes with increasing temperature and vice versa.On the other hand result in a lower temperature to reduce the viscosity of plasma, which is one of the most important factors affecting the red blood cells collected and thus influence the Rouleaux phenomenon and reduce the ESR values.It has the current study was to demonstrate the effect of temperature factor on sedimentation rates of red blood cells Due to the advantage by some Iraqi provinces from the significant rise in temperatures in the summer offset relative decline in the winter and see the effect of the degree of laboratory temperature (not fitted with means of

heating and cooling efficient) whether research of which belonging to hospitals or health centers different as well as interruptions continuing in power, as was the high temperature in the high moral values of sedimentation rates the values of $p<0.01$ and thus conclude that the temperature of 15 degrees is the best thermal testing can hold the sedimentation rate shows the effect of laser radiation on ESR forRBC levels increase with increasing the laser radiation. (In absenceof plasma) the red blood cells became important chieffactor of determining the erythrocyte sedimentation rate(ESR), to explain the increasing in ESR (L.) levels with increasing the dose laser radiation produce alteration in molecules by Intermolecular or intramolecular crosslinking is an effect caused by the creation of secondary bond between two molecules, (intermolecular crosslinking(or between two points of the same molecule, which were not linked before irradiation (intramolecular cross-linking) Crosslinking lead to increase the weight of molecule and decrease viscosity of the red bloodcells these leads to the increase of the ESR ${ }^{[7]}$. The irradiation of laser with a wavelength of $2100 \mathrm{~nm}$ showed a more effect than that of laser with wavelength of $632.8 \mathrm{~nm}$ on the ESR . 


\section{Conclusions}

The change of temperature (high and low) has a great effect on the deposition and precipitation of red blood cells in health people and thus must be taken into consideration and this effect is also observed with the use of $\mathrm{He}$ - Ne laser at a temperature of $15^{\circ} \mathrm{CWe}$ observe irradiation 632.8 $\mathrm{nm}$ laser decreases ESR while increasing irradiation at $2100 \mathrm{~nm}$ with $\mathrm{p}<0.01$.

\section{$\underline{\text { Recommendations }}$}

1. The need for a test deposition rate of red blood cells at temperatures ranging from (20-25) ${ }^{0} \mathrm{C}$.

2. equip laboratories (research centers or scientific) with conditioning and heating with high efficiency.

3. Study the impact of the type of material anticoagulant on the values of deposition rate and install the rest of the influencing factors.

\section{Reference}

1- Rhoades, R.A. and Tanner, G.A: Medical physiology. 2nd ed. Elsevier Philadelphia, Pennsylvania ,2012, Pp.(739) .

2- Turgeon, M.L.(Ed.) : Clinical Hematology, theory and procedures. 1st ed., Little ,Brawn and Company, Boston, 1998, 326pp .

3- AmmalEsmaeelIbrahim, SuhadAbdul AzeezIbrahim, DhuhaHashemFadhel, and Amir Adnan Hussein, Sedimentation Levels of Red Blood Cells (ESR) and its Effect on Viscosity of Blood Cells (PVC) and Glucose in Elderly People,
Journal of Al-Nahrain University,June 2014; Vol.17 (2): pp.9-12.

4- Kassak, P.; Sikurova, L.; Kvasnicka, P., and Bryszewska, M.: The response of $\mathrm{Na}+/ \mathrm{K}+-$ ATPase of human erythrocyte to green laser light treatment.

Physiological research.2006; Vol. 55: PP. 189-194.

5- JenanH.Taha BSc,Fikher S. AL-AniMBChB, MSc, PhD, Wijdan F. AL-Siaidy BSc, $\mathrm{PhD}$, Protection Properties of He-Ne Laser $(632.8 \mathrm{~nm})$ Against UV-light $(253.7 \mathrm{~nm})$ On the Lymphocytes Blood Cells and Its DNA , J Fac Med Baghdad 2012;Vol.54 No.3: pp.247-251.

6- AmalYousif Mohsen Al-Yasiri MSc, Effect of $650 \mathrm{~nm}$ Diode Laser on the Cross-Bonding Formation of Human RBC Membrane, Iraqi J. Comm. Med., July, 2009; Vol. 22(3) : pp.188-191 .

7- Ahmed A. Ibrahim: A new automated method for the determination of erythrocyte sedimentation rate ( ESR ), Journal of Kirkuk University Scientific Studies 2007; Vol.2,No.3, pp.64-69 .

8- Humański P, Dykczyński P. Leczenie $\mathrm{W}$ przypadkachkamicymoczowodowejen ergialaseraholmowegonaddzialeurolog iijednegodnia. UrologiaPolska (2008) ;Vol. 61,pp.142-146.

9- Rajesh Taneja , Soft Tissue Applications of Holmium Laser in Urology , JIMSA July-September 2011;Vol. 24 No.3:pp.135-136 .

10- WRHA Laboratory Medicine Program. "Guidelines for ordering erythrocyte sedimentation rate (ESR)". Effective Date 2004. [Clinical Guideline],from Diagnostic Services of Manitoba Inc. at Retrieved June 26, 2006; . 
11- Samira M. Sallam, Abdelsattar M. Sallam, El-Sayed M. El-Sayed, L. I. Abo Salem ,Mona M. Rizk , Enhancement of Human Blood Storage Period by Irradiation of Low Level He-Ne Laser, Journal of Biophysical Chemistry, 2015 ; Vol.6: pp.77-86.

12- Relevy, H., Koshkaryev, A., Manny, N., Yedgar, S. and Barshtein, G.Blood Banking-Induced Alteration of Red Blood Cell Flow Properties. Transfusion, 2008 ;Vol.48:pp. 136146 ,

13- Brill, A.G., Shenkman, B., Brill, G.E., Tamarin, I., Dardik, R., Kirichuk, V.F., et al.Blood Irradiation by He-NeLaser Induces a Decrease in Platelet Responses to Physiological Agonists and an Increase in Platelet
Cyclic GMP. Platelets,2000 ;Vol.11:pp. 87-93.

14- Ayad G. Anwer : Stimulation of Phagocytic Activity of Human Polymorphonuclear Leukocytes in Vitro Using $10 \mathrm{~mW}$ He-Ne Laser , Iraqi J. Laser, Part B, 2005 ;Vol.4, pp. 23-27.

15- Lewis,S.M.; Barbara,J.; Bain I.; Imelda B : Practical Hematology. 9th ed. Churchill Livingstone, 2001;pp.527-531

16- . Yousry M Mostafa, Sherif N Amin, Samir Abd al wahabandAlsayed AM Elsherbini : Effects of Non-Coherent and Coherent Light on Complete Blood Picture and Osmotic Fragility of Human Blood, Mostafa et al., J Blood Disorders Transf 2013;Vol.4 : pp.4-1. 


\title{
مقارنة بين مستوى ليزر عالي وواطئ القدرة ودرجة الحرارة على معدل ترسيب كريات

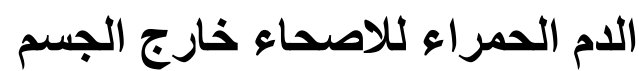

\author{
فريال يونس نزال
}

الخلاصة

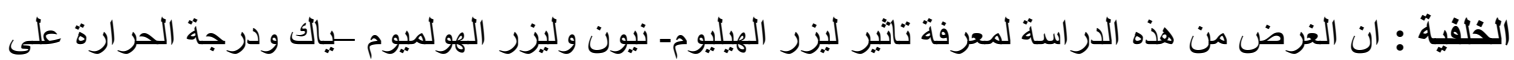

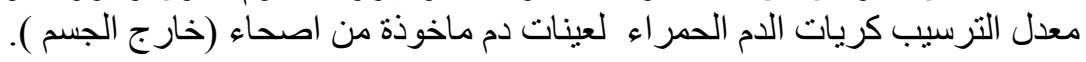

الهـف :اظهار تاثير ليزر الهيليوم - نيون وليزر الهولميوم -ياك ودرجة حرارة البيئة على معدل ترسيب كريات الدم الحمر تربيك.

طريقة البحث : استخدم مصدر ليزر الهيليوم- نيون بطول موجي

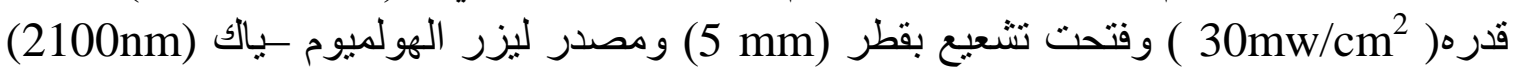

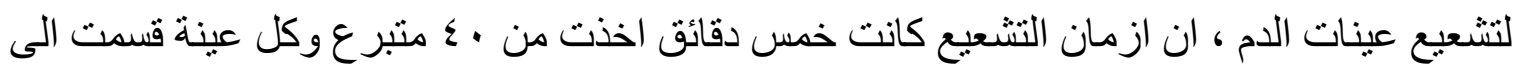
ثناث اقسام .

النتائج : اظهرت النتائج وجود فروق معنوية في قيم معدلات الترسيب عند المقارنة بدرجتي ( 10 ، 0 ــ ) درجة

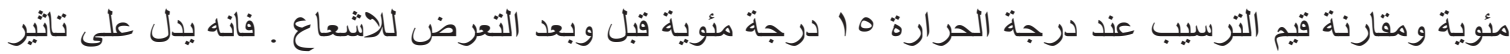

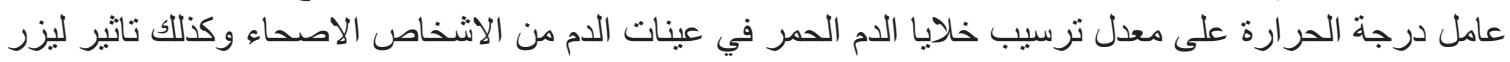

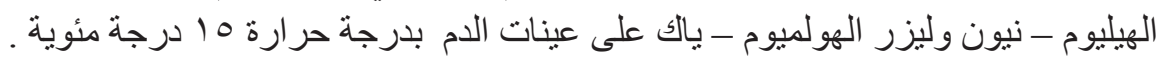

الاستنتاجات :يمكن الاستنتاج ان التغير في درجة الحرارة ( الارتفاع والانخفاض ) يؤثر على قيم معدلات ترسيب

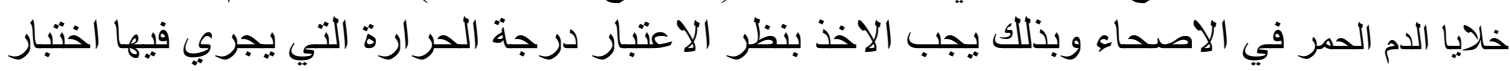

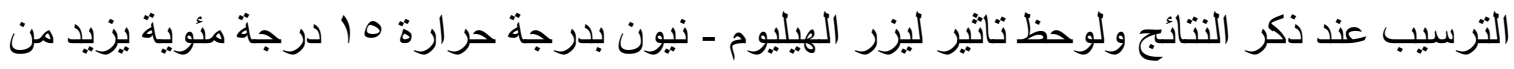

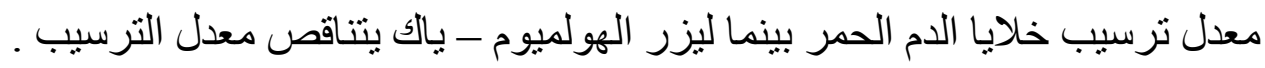

